\title{
The Names of Ex-Voto Objects in Ancient Mesopotamia
}

\author{
I. J. Gelb
}

\begin{abstract}
A
mong the Sumerians of ancient Mesopotamia there was a widespread custom of dedicating ex-voto objects to divinities by persons who wished thereby to secure for themselves and their families well-being, prosperity, and long life; to avert misfortune and sickness; or to express thanks for favors granted. These objects were dedicated to both male and female divinities; the offerers were usually the rulers, rarely private individuals.

The time of attestation covers practically the whole span of Sumerian history, beginning with Eannatum, Entemena, and Urukagina, who ruled in Lagash in the first half of the third millennium B.C., and extending down to Ur-Nammu, Shulgi, and BurSin, the rulers of the Third Dynasty of Ur, which was replaced toward 2000 B.C. by the dynasties of the Semitic Akkadians and Amorites. Our best attestation comes from the middle period, from the time of Gudea, the glorious ruler of Lagash. The custom of naming ex-voto objects passed on from the Sumerians to the Akkadians, but attestation among the latter is much more restricted.

Among named ex-voto objects found heretofore there are statues, stelae, weapons (such as maces), tables, bowls, musical instruments (such as lyres), and one example of a cylinder seal.

Our information concerning the names of the divinities, offerers, and ex-voto objects comes from either the inscriptions which are found on the objects, from tablets which accompany the ex-voto objects, or from other types of inscriptions whose aim is to describe the pious deeds of individuals making the offering.

The ex-voto objects are given names which are recorded as such in the inscriptions. Here are some typical examples of ex-voto names in the Sumerian tradition:
\end{abstract}


"Entemena-is-the-beloved-of-Enlil"

- the name of a statue dedicated by Entemena to Enlil ${ }^{1}$ "The-prayer-of-Urukagina-was-brought-to-Bau"

- on a tablet originally attached to an object, now lost ${ }^{2}$ "May-my-king(=god)-prolong-my-life"

- the name of a bowl dedicated by Ur-Ninsun to Ningirsu ${ }^{3}$ "For-my-king(=god)-I-built-his-temple, may-(long)-life-be-my gift"

- the name of a statue dedicated by Gudea to Ningirsu ${ }^{4}$ "Ningirsu,-the-king(=god)-whose-heavy-might-the-worldcannot-bear,-has-decided-good-destiny-for-Gudea,-who-builtthis-temple"

- the name of a statue dedicated by Gudea to Ningirsu ${ }^{5}$ "Good-destiny-was-decided-for-Gudea,-the-priest-of-Ningirsu"

- the name of a stela recorded in a long cylinder inscription describing the deeds of Gudea ${ }^{6}$

"Geshtinanna-looks-upon-me-with-a-favorable-eye"

- the name of a statue dedicated by Gudea to the goddess Geshtinanna ${ }^{7}$

"I-am-the-one-who-loves-his-god,-may-my-life-be-long"

- the name of a statue dedicated by Ur-Ningirsu to Ningishzida ${ }^{8}$

"O-my-king!(=god),-may-I-live-by-his-ear-of-favor"

- the name of a cylinder seal dedicated by Shulgi to Meslamtaea ${ }^{9}$

"Bur-Sin-is-the-beloved-of-Ur"

- the name of a statue recorded on a brick inscription of Bur-Sin ${ }^{10}$

1 C. J. Gadd and L. Legrain, Ur Excavations Texts I (London, 1928) No. 1.

2 W. Förtsch in Zeitschrift für Assyriologie XXXI (1917/18) 133.

${ }^{3}$ F. Thureau-Dangin, Die sumerischen und akkadischen Königsinschriften (Leipzig, 1907) p. 66.

4 Ibid. p. 72.

5 Ibid. p. 76.

6 Ibid.p. 114.

7 F. Thureau-Dangin, in Monuments et mémoires, publiés par l'Académie des Inscriptions et Belles-Lettres XXVII (1924) 104.

8 Ibid. p. 105.

9 Thureau-Dangin, Die sumerischen und akkadischen Königsinschriften, p. 194.

10 Ibid. p. 198. 
"May-my-lady(=goddess)-watch-over-me"

- the name of a bowl dedicated by a private individual to an unknown divinity. ${ }^{11}$

Some typical examples in Akkadian are:

"Nabu-is-the-guardian-of-the-boundary-of-the-fields"

- the name of a boundary-stone found inscribed on a boundary-stone ${ }^{12}$

"O-Adad! -the-war-like-lord,-give-water-in-abundance"

- the name of a boundary-stone ${ }^{13}$

"O-Ishtar! -to-you-is-my-ear-(turned)"

- the name of a statuette dedicated by an individual to Ishtar. ${ }^{14}$

The object of securing well-being and protection from the enemy not for one individual but for many is quite apparent in dedications of large man-made projects, such as canals and walls and gates of a city. They too bear names identical in type with those of the ex-voto objects:

"Ningirsu-is-the-prince-in-Nippur"

- the name of a canal dedicated to Ningirsu and recorded in an inscription of Urukagina ${ }^{15}$

"Who-is-like-Nanna?"

- the name of a canal dedicated to Nanna in an inscription of Ur-Nammu ${ }^{16}$

"By-the-command-of-Shamash-may-Hammurabi-have-noadversaries"

- the name of a wall of Sippar dedicated to Shamash and recorded in inscriptions of Hammurabi written in Akkadian and Sumerian ${ }^{17}$

"Shamash-gave-to-Samsu-iluna-manhood,-power,-and-(long)life"

$11 \mathrm{~J}$. Nougayrol, in Revue d'assyriologie XLI (1947) 27, AO 16651.

12 V. Scheil, Mémoires de la Délégation en Perse II (Paris, 1900) 91.

13 L. W. King, Babylonian Boundary-Stones . . . in the British Museum (London, 1912) p. 20.

14 Thureau-Dangin, in Revue d'assyriologie VI (1904) 133.

15 Thureau-Dangin, Die sumerischen und akkadischen Königsinschriften, pp. $52 \mathrm{ff}$.

16 Gadd and Legrain, Ur Excavations Texts I, Nos. 284 and 285.

17 I. J. Gelb, in Journal of Near Eastern Studies VII (1948) 270. 
-the name of a wall of Sippar recorded in inscriptions of Samsu-iluna written both in Akkadian and Sumerian ${ }^{18}$ "Adad-establishes-its-abundance"

- the name of one of the eight gates of Dur-Sharrukin recorded in an inscription of Sargon II of Assyria. ${ }^{19}$

Of clearly prophylactic character were lions and dogs sculptured in stone or clay, whose aim was to protect the city or the home from enemies. Their typical names are:

"Impetuous-hurricane,-irresistible-attacker,-overthrower-ofthe-rebels,-fulfiller-of-the-wish" and "suppressor-of-insurrection,-trampler-of-the-enemy-land,-who-repels-evil,-bringsgoodness"

- the names of two stone lions built by a governor and placed at the gate of the city Kar-Shulman-asharid ${ }^{20}$ "Strong-is-his-bark," "conqueror-of-the-enemy," "biter-ofhis-foe," "he-who-brings-goodness," "he-who-expels-evil"

- the names of dogs of clay, which where placed in pairs on either side of the threshold of the house in order to avert evil spirits. ${ }^{21}$

The words used for the names of ex-voto objects are $m u$ in Sumerian and shumum in Akkadian. These are the words that are also used in these languages for real proper names, such as those of persons, divinities, and places.

The structure of the names of ex-voto objects is quite similar to that of standard proper names in that both normally express sentences of the type: "May-Sin-give-life" or "Sin-has-given-life."

With parallelisms between the names of ex-voto objects and proper names thus established, we may now consider their differences and the difficulties involved therein. The first point of difference pertains to the relative length of the names. Generally

18 Cuneiform Texts ... in the British Museum XXXVII (London, 1953) Pls. 1-4 and duplicates.

19 D. D. Luckenbill, Ancient Records of Assyria and Babylonia II (Chicago, 1927) $\S 85$.

20 F. Thureau-Dangin and M. Dunand, Til-Barsib I (Paris, 1936) 143.

21 C. J. Gadd, in Revue d'assyriologie XIX (1922) 159 and O. R. Gurney, in Annals of Archaeology and Anthropology XXII (1935) 84 and 72. It is interesting to note that, as can be seen in the above articles, not only clay figurines of dogs but also rituals proscribing the use of such figurines for the purpose of exorcism have been discovered in Mesopotamia. 
speaking, the names of ex-voto objects are much longer than those of persons, divinities, and places. Often the names of ex-voto objects are so long as to give the impression of a prayer or a statement of thanks addressed to the divinity to whom the object is dedicated. These names are obviously too long for practical use.

The second point involves the reasons for naming ex-voto objects and the intended function of the names. If the reason for name-giving is the identification of the named thing, it is understandable that some large objects such as statues and stelae, might need special names to set them apart, but why were names also given to such insignificant objects as tables, bowls, and musical instruments?

We are led to the inescapable conclusion that the purpose in naming ex-voto objects is not solely identification. Speculating along different lines, we may conclude that: a) the existence of ex-voto names manifests a case of animistic tendency to endue things with life; b) names are given to ex-voto objects because living things exist only by having names; and (c) ex-voto objects serve as personal intermediaries between the votant and the divinity.

The types of names here discussed have never been collected or even discussed in the oriental literature known to me. They are apparently new to the field of onomastics, and they cannot be fitted into any typological scheme, as proposed in studies of names which I have consulted. ${ }^{22}$ The present paper, admittedly preliminary, is given here in the hope that it will further discussion of this interesting new subject.

22 Alan A. Gardiner, The Theory of Proper Names (Oxford, 1940); Ernst Pulgram, Theory of Names (Berkeley, 1954); George R. Steward, in Names I (1953) 73-78. 